SHORT COMMUNICATIONS

\title{
CONJUGATIONS WITH GLUTATHIONE DISTRIBUTION OF GLUTATHIONE S-ARYL TRANSFERASE IN WILD BIRDS
}

\author{
J G WIT \\ Institute of Veterinary Pharmacology and Toxicology, University of Utrecht, Utrecht, The Netherlands
}

Recelved 21 November 1968

Accepted 6 December 1968

\begin{abstract}
J G.WIT, Conjugations with glutathone Distribution of glutathione S-aryl transferase in wild birds, European J Pharmacol 5 (1968) 100-102

Enzymes present in the high speed supernatants of wild bird livers (pheasant, coot, great crested grebe, goosander, eider, tufted duck and common gull) conjugate chlonnated nitrobenzenes and 4 nitropyridine N-oxide with glutathione (replacement of $\mathrm{Cl}$ atoms or nitro groups).
\end{abstract}

\author{
34 dichloro nitrobenzene \\ 24 dinitro chlorobenzene \\ 23. 5.6 te trachloro nitrobenzene \\ 4 nitropyridine N-oxide
}

enzymic replacement of

$\mathrm{Cl}$ or nitro groups

wild burd liver supernatant

\section{INTRODUCTION}

Al-Kassab, Boyland and Willams (1963) and Booth, Boyland and Sims (1961) reported enzymic glutathone conjugations with chlorinated nitrobenzenes by rat liver supernatant Grover and Sims (1964) studied the distribution of glutathione S-aryl transferase in invertebrate species. A similar study was made by Cohen, Smith and Turbert (1964) in locusts and other insects $W_{1}$ and Snel (1968) demonstrated the presence of enzymes, conjugatıng glutathione with an epoxyde and an unsaturated compound, in wild bird livers.

The present study is a further examination of enzymes present in wild bird livers which catalyse the replacement of $\mathrm{Cl}$ atoms or nitro groups from chlorinated nitrobenzenes and 4 nitropyndine $\mathrm{N}$-oxıde.

\section{METHODS}

Pheasants, coots, great crested grebes, goosanders, tufted ducks and a common gull (juv.) were shot near Lelystad (Flevopolder, The Netherlands) during the winter 1967-1968. The livers were removed $1 \frac{1}{2}-6 \mathrm{hr}$ later and were kept on ice during the night The t1ssues were homogenized with 4 vol. of $01 \mathrm{M} \mathrm{Na}-\mathrm{K}$ phosphate buffer ( $\mathrm{pH} 74)$ and the homogenates were centrifuged for $1 \mathrm{hr}$ at $70000 \mathrm{~g}$ (ave) The clear supernatant was stored at $-20^{\circ}$ unless used immediately Female eiders were shot on the Vleland island (The Netherlands) in June 1968 The livers were removed immediately and kept in dry ice for $16 \mathrm{hr}$. After thawing, parts were taken and homogenized with 5 vol. of $0.25 \mathrm{M}$ sucrose ( $1 \mathrm{mM}$ diNa EDTA, pH 74 ) The homogenate was centrufuged for $30 \mathrm{~min}$ at $480 \mathrm{~g}$ (ave), $5000 \mathrm{~g}$ (ave) and $11.000 \mathrm{~g}$ (ave) to remove cell debris and coarse particles The supernatant was centrifuged for $1 \mathrm{hr}$ at $78000 \mathrm{~g}$ (ave) and the clear supernatant of this preparation was stored at $-20^{\circ}$ when not used immediately

The enzyme activity towards 34 dichloro nitrobenzene and towards 24 dinitro chlorobenzene was determined according to Booth et al (1961) and Cohen et al. (1964) respectively. The enzymic conjugations of 2.3.5.6 tetrachloro nitrobenzene and of 4 nutro pyridine $\mathrm{N}$-oxide with glutathione were measured by estimating the release of nitrite-1ons (Al-Kassab et al., 1963) The concentrations employed were 

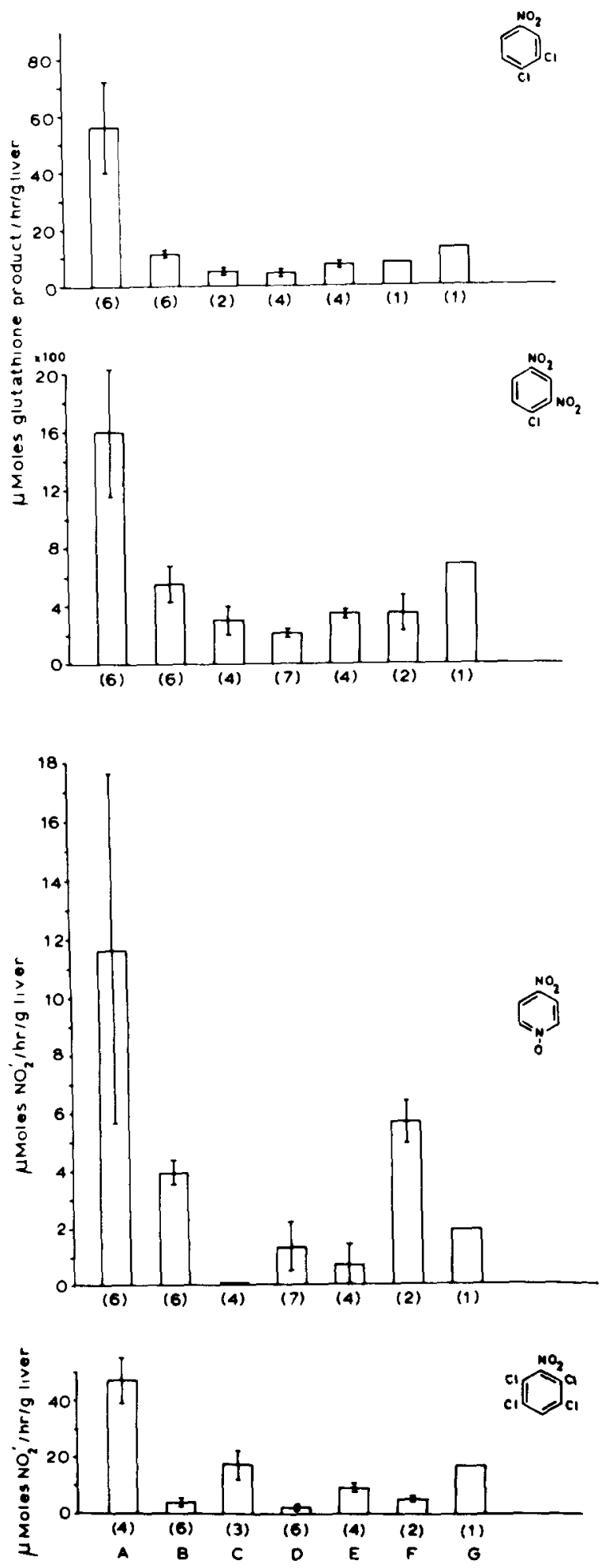

$125 \mathrm{mM}$ and $375 \mathrm{mM}$ for the substrates 34 dichloro nitrobenzene and glutathone, $10 \mathrm{mM}$ and $50 \mathrm{mM}$ for 24 dinitro chloro benzene and glutathione, 01 $\mathrm{mM}$ and $60 \mathrm{mM}$ for 235.6 tetrachloro nitrobenzene and glutathione, $05 \mathrm{mM}$ and $60 \mathrm{mM}$ for 4 nitro pyridıne $\mathrm{N}$-oxıde and glutathone respectıvely

\section{RESULTS}

The activities per $g$ liver are given in fig 1 (mean \pm $\mathrm{SD}$ )

\section{DISCUSSION}

On examınation of the activities of wild bird liver preparations towards glutathione conjugations with an epoxyde ( 23 epoxy phenylpropylether) and with an unsaturated compound (diethylmaleate), Wit and Snel (1968) observed a remarkably high activity in pheasant liver in comparison with the livers of coots, great crested grebes, goosanders, tufted ducks and common gull The same feature was found when chlorinated nitrobenzenes and 4 nitro pyridine $\mathrm{N}$ oxıde were used as substrates for glutathone S-aryl transferase in wild bird liver preparations in vitro (fig 1) 4 Nitropyridine $\mathrm{N}$-oxide, however, was not a suitable substrate for the liver preparation of the great crested grebe.

Al-Kassab et al. (1963) found a close relationship between, if not identity of, the properties of rat liver glutathione S-aryl transferase respectıng the re-

Fig 1 Enzyme activities of glutathione S-aryltransferase in wild bird liver preparations. The ordinate represents the products formed per hour per $g$ liver (mean \pm S.D) On the absc1ssa the figures between brackets represent the number of burd livers examined The employed substrates are, reading from above 34 dichloronitrobenzene (4-Cl replaced), 24 dinitrochlorobenzene ( $\mathrm{Cl}$ replaced), 4 nitro pyridine $\mathrm{N}$-oxide and 2.3.5.6 tetrachlorontrobenzene (replacement of the nitro groups). $\mathrm{A}=$ pheasant (Phasianus colchicus), $\mathrm{B}=\mathrm{coot}$ (Fulica atra), $\mathrm{C}=$ great crested grebe (Podiceps cristatus), $\mathrm{D}=$ goosander (Mergus merganser), $\mathrm{E}=$ e1der (Somaterla mollissima), $\mathrm{F}=$ tufted duck (Aythya fullgula) and $\mathrm{G}=$ common gull (juv) (Lanus canus) 
placement of $\mathrm{Cl}$ atoms or nitro groups $\mathrm{W}_{1}$ and Leeuwangh (1968) also found a close similarity between the glutathone S-aryl transferase properties in rat liver and pigeon liver preparations Species differences became apparent when competitive substrates were used The absence from liver preparations of the great crested grebe of an enzyme releasing $\mathrm{NO}_{2}$-10ns from 4 nitropyridine $\mathrm{N}$-oxide indicates an additional species differsnce among birds

Wit and Snel (1968) speculated upon the possible involvement of dietary factors in the evolution of enzymes dealıng with the metabolısm of foreign compounds, suggesting that carnivorous birds are less likely to encounter foreign substances in their ndtural diet than are the herbivorous species. An extension of this view might be that birds which mainly eat seeds would be better able to inactivate foreign compounds than birds with a less specialized vegetable diet $\mathrm{c} f$ the pheasant and the coot. This aspect needs further attention

Most compounds containıng nitro groups are manmade and it was of interest to know if natural nitro compounds were known to exist in the plant kingdom Besides chloramphenicol, references were found in the literature to azomycine (2 nitro imidazol, occurring in Nocardla mesentenca and in $S$. euroctdicus, see Umezawa (1967)), $\beta$-nitropropionic acid occurrnng in "Trailıng indigo" (Indtgofera endecaphylla Jacq) and in Vlola odorata (Sweet violet) and the "Aristolochia acids", occurring in several species of the Aristolochuaceae (see Pailer, 1960) These findıngs may ind1cate that organic nitro compounds are met more often by herbivores than by carnivores.

The results of the present investigation demonstrate the presence of glutathione S-Aryltransferase activity in the livers of wild bird species but caution towards an extrapolation of the in vitro experiment to metabolic routes in vivo is recommended.

\section{ACKNOWLEDGEMENTS}

The stimulating discussions with prof $\mathrm{H}$ van Genderen and the corrections of the English style of the manuscript by Prof Dr K M Dyce are gratefully acknowledged The technical help by $\mathrm{Mr} \mathrm{H} \mathrm{H}$ vander Werff is gredtly appreciated

\section{REFERENCES}

Al-Kassab, S , E Boyland and K Willams, 1963, An enzyme from rat liver catalysing conjugations $w 1$ th glu tathione Replacement of nitro groups, Biochem J 87,4

Booth. J , E Boyland and P Sims, 1961, An enzyme from rat liver catalysing conjugations with glutathone, Biochem J 79,516

Cohen, A J, J N Smith and H Turbert, 1964, Comparative detoxication The enzymic conjugation of chloro compounds with glutathione in locusts and other insec ts, B1ochem J 90.457

Grover, P L and P Sims, 1964, Conjugations with glutathione Distribution of glutathione S-aryl transferase in invertebrate species, Biochem J 90,603

Pailer, M , 1960. Naturlich vorkommende Nitroverbindungen in Fortschritte der Chemie organischer Naturstoffe, ed L Zechmeister (Springer-Verlag, Wien) vol 18, p 55

Umezawa, H , 1967, in Index of antibiotics from Actinomycetes, ed $\mathrm{H}$ Umezawa (University of Tokyo Press, Tokyo) p 168

Wit. J G and P Leeuwangh, 1968, Mercapturic acid formation and enzyme catalysed conjugations with glutathione in pigeons, Biochim Biophys Acta, in press

Wit, J G and J Snel, 1968, Enzymatic glutathone conjugations with 2,3-epoxyphenyl propylether and diethylmaleate by wild bird liver supernatant, European J Pharmacol 3, 370 